\title{
The origin of the Tocharian A plural ending -äm
}

\author{
Alessandro Del Tomba \\ Sapienza, University of Rome and Leiden University \\ alessandro.deltomba@uniromar.it
}

\begin{abstract}
The aim of the present article is to trace the origin and the evolution of the Tocharian A ending -äm, which is the plural marker of a closed class of nouns, whose Tocharian $B$ counterparts are ranged under other inflectional classes. The results of this investigation are twofold: (1) not only is Tocharian A shown to have generally preserved the Proto-Indo-European situation better than Tocharian B, (2) but it is also argued that some members of this closed class are relevant from an Indo-European comparative perspective, since they have refunctionalised the $n$-form of the PIE $* / n$-stems as a plural marker.
\end{abstract}

\section{Keywords}

Indo-European - Tocharian - heteroclites - inflection - blending

\section{Introduction}

In contrast to the verbal system, it is generally held that the Tocharian nominal system is less conservative and archaic with respect to what is reconstructed for Proto-Indo-European. This is, however, only partially true. Some Tocharian nominal endings and forms can in fact prove relevant from a comparative perspective. I believe this is the case with the Tocharian A inflectional class with the plural ending -äm (nom. = obl.).

This case marker is historically compared with TchB -na, as they are usually considered to be the outcome of the original neuter plural of nasal stems, which underwent reanalysis: PIE * $n-h_{2}>^{*}-n-\breve{a}>$ PTch *-na > TchB -na, A - $(\ddot{a}) m$ (Pinault 2008: 493 f.). For this reason, Krause \& Thomas (TEB §162) grouped nouns with these plurals together under a single nominal class (II.1). Despite 
TABLE 1 Tocharian A nouns with plural -äm and their Tocharian B correspondents

\begin{tabular}{llllll}
\hline Tocharian A & & Class & Tocharian B & Class \\
sg. & pl. & & sg. & pl. & \\
\hline por 'fire' & poräṃ & II.1 & puwar 'id.' & pwāra & I.1 \\
ysār 'blood' & ysāräm & II.1 & yasar 'id.' & ysāra & I.1 \\
ytār 'road' & ytāräṃ & II.1 & $\begin{array}{l}\text { ytārye 'id'. } \\
\text { owreme '?' }\end{array}$ & ytarim (obl.) & VI.1 \\
wram 'thing' & wramäm & II.1 & plāce 'id.' & plāci (nom.) & V.2 \\
plāc 'word' & plācäm & II.1 & & plātäm (obl.) &
\end{tabular}

the alleged common origin, however, TchB -na and TchA - $\ddot{a} m$ have a different distribution. Indeed, there are no Tocharian B nouns with plural in -na matching Tocharian A nouns with plural in -äṃ. Their productivity is different as well: TchB -na is the plural marker of a fair number of nominals, while TchA -äm is confined to five substantives only. This mismatch is peculiar.

As can be seen from Table 1, the cognate nouns in Tocharian A and B belong to different inflectional classes.

Of the five Tocharian A nouns, three are of alternating gender (TchA por, TchA ysār, TchA wram), and two are of feminine gender (TchA ytār and TchA pläc).

The core issue is which of the two languages preserves the older state of affairs, and the present article aims to answer this question, analysing the synchronic distribution and the diachronic evolution of this ending in Tocharian. I intend to show that Tocharian A has generally preserved the original situation, while Tocharian B has mostly recharacterised the plural form of these nouns. If my analysis is correct, it would also confirm that this inflectional class is relevant to the reconstruction and the further development of an archaic Proto-Indo-European class of nouns: the ${ }^{*} r / n$-heteroclites.

\section{$2 \quad$ Etymology of the nouns}

Three of the five Tocharian substantives that belong to class II.1 can be traced back to PIE heteroclites.' They are: TchA por, B puwar 'fire', TchA ysār, B yasar

1 The connection of these Tocharian nouns with the PIE * $r / n$-stems has already been proposed 
'blood', and TchA ytār, B ytārye 'road'. That these nouns reflect PIE * $r / n$-stems was actually noted decades ago, but the relevance of this fact for their plural formation has not, to my knowledge, been explicitly pointed out.

Cognates of TchA por, B puwar 'fire' are found in most Indo-European languages. Among these, Hitt. paḩૂur, gen.sg. pahhuenaš continued the proterodynamic inflection almost intact and thus provides substantial evidence for reconstructing the heteroclitic paradigm as PIE " $p e ́ h_{2}$-urr, " $p h_{2}$-uén- (Kloekhorst

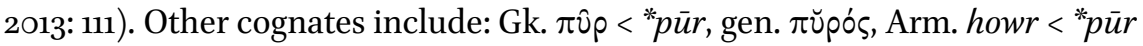
(Olsen 1999: 94), Umbr. pir < " pür (cf. acc. sg. sim 'pig' < * suH-m), abl. pure <

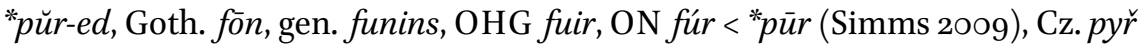
'burning ash' (Machek 1957: 502). There is no doubt that both TchA por and TchB puwar are somehow linked to these formations. However, the exact apophonic grade and morphological formation from which they descend are notoriously problematic, since the phonological correspondence between TchA -oand TchB /-əwa-/ is difficult and complicates the Proto-Tocharian reconstruction. However, given the fact that the exact origin of these nouns is not important for our discussion, I will not go deeper into their etymology here. ${ }^{2}$

As far as TchA ysār, B yasar /yásar/ 'blood' is concerned, it has cognate forms in several Indo-European languages, including Hitt. ēšhar, gen. išhanāšs, Skt. ásr-k, gen. asnáh, Gk. žap ทे $\alpha \rho$, Latv. asins, OLat. as(s)yr (Paul. Fest. 12. 19; cf. also aser in CGL 2.23,56 and the derivative OLat. assarātum, a kind of "bloody" drink, de Vaan 2008: 58), perhaps Lat. sanguen (Ennius, Ann. 108) sanguis, Arm. ariwn, etc. These forms may allow us to posit PIE ${ }^{*} h_{1} e ́ s h_{2}-r$, ${ }^{*} h_{1} s h_{2}$-én-. The Tocharian words can easily be derived from this proto-form (Kortlandt 2010:146). Otherwise, they may also be the outcome of the collective ${ }^{*} h_{1} e ́ s h_{2} \bar{o} r$ (Hilmarsson 1986: 22; Pinault 2011: 163; Adams DTB: 525).

in the past by leading scholars, like Van Windekens (1944: 79 ff.) and Hilmarsson (1984), but their treatments are in many points different from mine. Furthermore, a systematic analysis of this Tocharian A class is still missing. Recent investigations on the outcomes of some heteroclitic formations in Tocharian are Pinault (2011), Malzahn (2014), and Kim (2019).

2 Winter (1965: 192 f.) was the first to claim that Tocharian A and B point to different preforms: TchA por would continue PIE * pé $h_{2}$-urr, while TchB puwar would be from PIE * $p u h_{2} r$. Other scholars propose that the word for 'fire' retained both regular and collective stems in ProtoTocharian: Tocharian A would continue the former, Tocharian B the latter. This reconstruction has recently been advocated by Kim (2019: 145). However, I believe that multiplying the number of proto-forms that cannot belong to the same morphological paradigm is questionable and quite unlikely. Indeed, if Tocharian inherited both the regular and the collective formation of this noun, it is highly probable that it had already generalised one of the two paradigms before the breakup of Proto-Tocharian. For other suggestions, see Schindler (1967: 242-244), Hilmarsson (1985: 42-43 and 1989: 135, followed by Hackstein 2017), and Ringe (1996: 17-18). 
Finally, both TchA ytār and TchB ytārye /y(ə)tárye/ 'road, street, path' are of feminine gender. These words must be compared with Lat. iter, gen. itineris, and the derivative YAv. pairiona 'the course of life' (Yt 8.54, Panaino 199o: 141). ${ }^{3}$ Tocharian continues the collective PIE * $h_{1}$ - -tốr (Hilmarsson 1986: 44; Pinault 2011: 163-164; Adams DTB: 559; Kim 2019: 145). ${ }^{4}$ The unexpected feminine gender in both Tocharian A and B, and the element -ye /-(ə)ye/ in Tocharian B are problematic. ${ }^{5}$ Indeed, this noun should be reconstructed as neuter for ProtoIndo-European. It follows that the feminine gender of TchA ytār, B ytārye must be secondary, because PIE neuter nouns are usually continued as alternating in Tocharian. In my opinion, in the Proto-Tocharian phase, this substantive was influenced by the ancestor of the productive feminine noun TchB kälymiye, A kälyme 'direction, region' because of its meaning, so that PTch *yatar at first acquired feminine gender. Since the gender of TchA kälyme also fluctuates between alternating and feminine (Carling 2009: 176; Peyrot 2012: 212), one might assume a case of mutual influence. Subsequently, after the dissolution of Proto-Tocharian, it shifted inflectional class in Tocharian B, becoming a noun of the kälymiye-type. ${ }^{6}$

3 As one of the anonymous reviewers informed me, the oft-cited Hitt. itar (alleged hapax legomenon in KUB 41.8 i 20, cf. Rieken 1999: 374-377; Kloekhorst 2008: 422) has recently been read by Miller (2008: 209 fn. 97) as DUMU-tar 'offspring'.

4 One might object that, from the semantic point of view, the assumption of an original collective * $h_{1} i t o \bar{r}$ is difficult, as neither TchA ytār nor TchB ytärye denotes a multitude of streets and it cannot be proven that they did so at an earlier stage either. Nussbaum (2014a: 251) points out this problem and convincingly suggests that this (morphological) collective formation has an "instantial" value, i.e. "denotes [...] an individual instance of an action, event, or state"

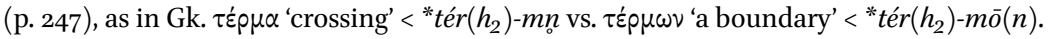

5 Hartmann (2013: 470-472 and 519-520) has recently commented on the previous interpretation of TchB ytārye and has further posited PIE * $h_{1} i-t \bar{r} r-i h_{2}$ (Klingenschmitt 1994: $396 \mathrm{fn}$. 140) or * $h_{1} i-t \bar{r} r-\bar{e} n$ (Hilmarsson 1987: $48 \mathrm{f}$.). The first reconstruction is unsatisfactory from a phonological point of view, because PIE ${ }^{*}-i h_{2}$ should have evolved into TchB ${ }^{-}{ }^{y} a$. The second reconstruction has to cope with chronological and morphological inconsistencies, since it implies that an original *yatar, the regular outcome of PIE * $h_{1} i t o ̂ ́ r$, first became *yataraye (continued without modifications in TchB ytārye) and then turned to be *yztar $>y t a \bar{r}$ in Tocharian A, according to the model of TchA ysār 'blood'.

6 Cf. Pinault (2015: 189). Malzahn (2014: 200) tentatively tries to analyse the irregular feminine gender of these nouns as an archaism, by comparing it with Homeric Gk. of unexpected feminine gender (see also Leukart 1987:355). In parallel, Nussbaum (2014: 253) also claims that there is no reason not to interpret the feminine gender of this noun as original, because the other continuants in *-or inherited by Tocharian are alternating. However, this statement can also be read the other way around: since the other continuants of *-or are alternating in Tocharian, ${ }^{*} h_{1} i t o ̂ ́ r$ should originally have been neuter too and thus expected to evolve as an alternating. 
The two last substantives that belong to Class II.1 are TchA wram, TchB 'wreme 'thing, object, matter' and TchA plāc, B plāce 'word'. They do not go back to heteroclitic stems.

Following Van Windekens (1976: 580-581), TchA wram can be the exact cognate of Gk. $\hat{\eta} \mu \alpha,-\alpha \tau \circ \varsigma$ 'statement, word', since both Greek and Tocharian A point to an action noun PIE * uréh ${ }_{1}$-mn. Final-e in TchB käkse-wreme'?' (attested twice in B197, a Sanskrit-Tocharian bilingual dealing with matters of Abhidharma, cf. Kudara 1974 and Catt 2016) probably reflects a secondary thematisation in compounds (cf. the Greek type $\sigma \tau \tau^{\prime} \mu \alpha$ 'mouth' vs. ${ }^{\circ} \sigma \tau \mu \mu{ }^{\prime}$, as one of the reviewers has reminded me). ${ }^{7}$

As far as TchB plāce, A plāc 'word' is concerned, Tocharian B attests remnants of the hysterodynamic * $i$-inflection, allowing us to reconstruct PIE * $(s) p l H-t i$, from PIE *(s)pelH- 'to proclaim, speak solemnly' (cf. TchAB pälā- 'to praise', Pinault 2008: 345 ; contra Klingenschmitt's derivation from PIE * $b^{h} e l h_{1}$ - 'to yell, roar', 1994: 127). ${ }^{8}$

Now that we have clarified what type of PIE stems are continued in the Tocharian A class II.1, we can move forward with the origin of the plural ending TchA - äm.

There are two opposing ways to explain the plural forms of the nouns discussed above: (1) either Tocharian B has preserved the original situation and Tocharian A has introduced the morpheme - $(\ddot{a}) m<$ PTch *-na from other stems, or (2) Tocharian A has preserved the original situation and in Tocharian B the nasal plural *-na has been lost.

At first sight, both hypotheses seem plausible. The former implies that Tocharian A actually inherited plural forms identical to those of Tocharian B. When final vowels were deleted in Pre-Tocharian A, nominative and oblique would have become homophonous in both the singular and the plural. In order

7 I see no reason to reconstruct either Pinault's *urhh ${ }_{1}-0-m o-$ (2008: 512) or Adams' *urē-mēn(DTB: 672). Although these preforms have the advantage of deriving both Tocharian A and B words from a common ancestor, the former does not take into account the unproductive plural ending TchA - $\ddot{a} m$, while the latter requires an unwarranted lengthened grade in both the root and the suffix.

8 See further Malzahn \& Fellner (2015: $72 \mathrm{fn}$. 36). In the same inflectional class, we also find TchB maśce 'fist', which is to be equated with IIr. *musti- 'fist' (cf. Skt. muștí-, Av. mušti-), although the Tocharian word continues a nom.sg. PIE ${ }^{*}-t \bar{e}(i)$ of the hysterodynamic type, instead of the expected *-ti-s in Indo-Iranian (Pinault 2013: 346 f.; Adams DTB: 476). 
to reintroduce a distinction between singular and plural, the plural morpheme - äm would have been attached at a later stage (e.g. pl. PTch *yəsara $>$ Pre-TchA * ysār >> TchA ysāräm). This hypothesis also has to cope with some problems, however. As stated in the opening section, the fact that the marker TchA -äm is the least productive among the plural endings of Tocharian A must be seriously considered if its origin is to be traced. As a consequence, analogical developments can hardly be involved: basically, there is no immediate source where the plural * $\ddot{a} m$ could have been abstracted and then generalised. ${ }^{9}$

I therefore believe that the latter scenario is the correct one, since it lends itself to a more elegant solution: the nasal element in TchA -äm must be interpreted as an archaism not only in TchA wram 'thing, object', which goes back to an old ${ }^{*} m e n$-stem, but also in those words that continue heteroclitic ${ }^{*} r / n$ stems, where the plural -äm historically coincides with the original $n$-form. It follows that Tocharian A, as opposed to Tocharian B, has continued the heteroclitic inflection, by refunctionalising the $n$-form of the oblique cases in the plural. This is not an isolated trend of development, since it closely resembles similar cases in Latin and Iranian.

In the history of Latin, the old heteroclites are normalised in two ways (Ernout 1914: 67-68; Leumann 1977: 359-36o; Weiss 2009: 240f.). On the one hand, some nouns have analogically levelled the $r$-stem in all cases (e.g. Lat. über, -eris 'udder; abundant', cf. Skt. $\bar{u}$ dhar/n- 'udder'), although in Old Latin a few of them were still heteroclitic. Compare, for instance, Lat. femur, gen. femoris 'thigh' (e.g. in femore, Cicero, Verr. Or. IV. 43, 93) with OLat. femur, gen. feminis 'id.' (e.g. femina in Plautus, Poen. 3.1, 68). On the other hand, nouns like iter, gen. itineris 'street, way, journey' or iecur, gen. iocineris 'liver' show spread of the $r$-stem from the strong cases to the $n$-stem of the weak cases. It follows that in the pre-history of Latin two paradigms of the word for 'way, street' can be virtually reconstructed: older *iter / *itinis and newer *iter / *iteris (Leumann 1977: 103). Latin speakers mixed up the two paradigms, forming a new inflection with a stem *itin-er-, from a pre-existing ${ }^{*}$ itin-, in all weak cases and in the plural. Only the nominative and accusative singular still attest the original distribution of the allomorphs.

9 An anonymous reviewer points out that TchA -äm could have been introduced from the neuter nasal stems. However, the only noun that diachronically goes back to a "men-stem and synchronically shows this ending is namely wram 'thing, object', because other continuants of the PIE *men-stems have replaced their original plural forms, like TchA ñom 'name', pl. ñomäntu (cf. TchB ñem, pl. ñemna < PTch *ñcemna). This evidence implies that *äm was not a convenient plural ending in Pre-Tocharian A. There is therefore no reason why words like TchA por 'fire', $y t a \bar{r}$ 'road', and $y s \bar{a} r$ 'blood' should have selected this ending, and not other much more productive plural markers. 
TABLE 2 Heteroclitic inflection from PIE to Tocharian A

\begin{tabular}{|c|c|c|c|c|c|c|}
\hline & PIE & Pre-PTch & & PTch & Pre-TchA & $\mathrm{Tch} A$ \\
\hline Strong stem & *it-ór $r$ & $>$ *yat-ar & sg. & > *yatār & > *yätār & > ytār \\
\hline Weak stem & ${ }^{*} i t-n-$ & > *yat-an- & pl. & > *yatə-na & >> *yätāar-än $(\bar{a})$ & > ytāräm \\
\hline
\end{tabular}

Let us now consider some examples from Iranian. In Khotanese, spellings with double -rr-are the result of consonant clusters beginning with the vibrant (e.g. Khot. ttarra- 'grass' < "trna-, cf. Skt. trína-; Khot. kārra- 'deaf' < *karna-, cf. YAv. karəna- 'ear [daēvic]; deaf', Ved. kárṇa- 'ear', Emmerick 1969: 69). For this reason, OKhot. gyagarra- 'liver' is traced back to *iakrna- by Emmerick (1980: 168). In parallel, the numeral OKhot. byūrru '10.00o, myriad' can be the outcome of PSaka *baiwarnam (Emmerick 1980: 168 and 1993: 292; cf. Bailey 1979: 309). Although no clear Indo-European cognates of this word have been identified so far, OKhot. byūrru has some cognates in several Iranian languages, from both the Western (e.g. Pahl. be war, Parth. bywr) and the Eastern side (e.g. Sogd. Brywr 'myriad', Iron birce, Digor be (w)arce, cf. Cheung 2002: 65), including YAv. baēuuara/bāeuuan-, which points to the reconstruction of a heteroclitic ${ }^{*} r / n$ stem for Proto-Iranian. ${ }^{10}$

It is reasonable to assume that the same mixture of the two stems has affected the words for 'fire', 'blood', and 'road' in the Pre-Tocharian A stage. In Proto-Tocharian, these words must have continued the heteroclitic inflection, with $r$-stem in the singular and $n$-stem in the plural. Then, when Tocharian B and A split off from Proto-Tocharian, the former generalised the $r$-stem, and the latter refunctionalised the two stems, adding the reanalysed nom.obl.pl. PTch ${ }^{*}-n a<$ PIE *-nh $h_{2}$ to the $r$-stem (cf. Table 2). ${ }^{11}$

As Hock (1991: 189 f.) has pointed out, in analogical changes old and innovative forms have to coexist as variants for some time before the effective realisation of the analogy. Occasionally they are affected by blending (sometimes also called contamination). The phenomenon of blending is usually treated as a sporadic lexical change by which a new word is created through the combination of two already existing lexemes. In some cases, however, blending also

10 Cf. Mayrhofer (KEWA II.514): "Fraglich ist ein Zusammenhang von aw. baèvar-/baèvan".

11 Other survivals of PIE ${ }^{*} r / n$-stems may have formed their plural as nouns of class II.1 in

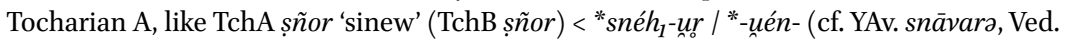
snávvan-). Unfortunately, the plural of this noun is only attested in TchB șñaura, but one might reconstruct șñoräm* for Tocharian A. 
affects the morphological paradigm of words, especially when they develop competing stems. This is exactly what has happened to the three Tocharian A nouns. In Proto-Tocharian, the two stems were therefore maintained for some time, particularly because they had different grammatical functions: the $r$-stem was used to express the singular, and the $n$-stem the plural. But the entire paradigm was analogically levelled, and the $r$-stem became the basis on which the $n$-containing endings were added. Through this development, the functional correspondence between singular and plural has been formally maintained, and PTch *-na has become a new plural marker. ${ }^{12}$

On the other hand, the competitive $r$ - and $n$-forms have developed differently in Tocharian B: the entire paradigm of these nouns was levelled in favour of the $r$-stem, while the $n$-form vanished. This is a common trend of development that also characterised some other Indo-European languages. Examples include: Lat. über, gen. überis 'udder' (cf. Skt. údhar, gen. údhnas, Gk. oîंap,

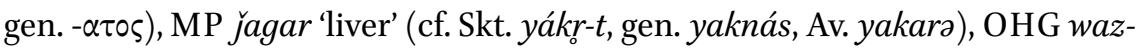
zar 'water', OE water 'id.' vs. Goth. wato (n-stem) 'water', ON vatn 'id.' (cf. Hitt.

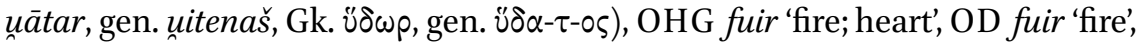
OE fÿr 'id.' vs. Goth. fon 'fire', ON funi 'flame' (cf. Hitt. pahhur, gen. pahhuenaš), and see further the doublet Goth. sauil 'sun' vs. Goth. sunno 'id.' (cf. OAv. huuar̆̌̆, gen. $x^{v} \bar{\partial} n g$ ).

A similar analysis, mutatis mutandis, also accounts for TchA wram 'thing, object', whose plural wramäm may go back to *uréh $h_{1}-m n-h_{2}>{ }^{*}$ wrēmnă $>$ PTch * wŕcemna. On the other hand, I was not able to find any clear explanation for the plural plācäm 'words' (cf. pläcänyo 'because of words' in e.g. A75 b6). Indeed, among the words discussed above, this is the only case where Tocharian B attests remnants of the original inflection (cf. nom.pl. TchB plāci< PTch *palacaya < PIE *(s)plH-tei-es). A tentative analysis suggests that TchA plāc acquired the plural ending from TchA wram. The reason this analogical development took place lies in the meaning of these nouns. Indeed, TchA wram had to originally mean 'speech, word', as the etymology of the term seems to indicate. For a certain period, TchA wram and TchA plāc were consequently almost synonyms, and this has favoured the transfer of the ending -äm to the paradigm of pläc. Only at a later time would TchA wram have developed the meaning of 'object'.

12 One may wonder whether this phenomenon can be regarded as a process of exaptation, a term introduced into linguistics by Lass (199o), according to which linguistic relics can be refunctionalised by being adapted according to existing regular templates. 
This article has focused on the diachronic evolution of Tocharian A nouns with the plural ending - $\ddot{a} m$. With the exception of TchA $p l a \bar{c}$ 'word', we have seen that these substantives can be traced back to PIE * $r / n$-stems (TchA ytā 'road', ysār 'blood', por 'fire') and to PIE * men-stems (TchA wram 'thing, object'). My final aim was to demonstrate that the plural ending TchA -äm constitutes a precious archaism that in a way continued the Proto-Indo-European state of affairs. We have seen that the reconstruction of heteroclitic nouns requires strict comparisons between the older stages of the Indo-European languages, because in more recent times the same languages generalised one of the two stems. In Tocharian B we found precisely this development: the formal contention between $r$ - and $n$-stems was resolved with the victory of the former over the latter. The final result of this process caused the collapse of the $n$-stem. On the other hand, we have seen that Tocharian A preserved the older state of affairs, since it has maintained both the $r$-form of the singular and the $n$-form of the plural. The final outcome of this development is a blended plural with the $r$ form as the stem and the $n$-form as the ending. This inflectional class therefore constitutes an important section of the Tocharian lexicon that offers a small but significant contribution to the diachronic evolution of Indo-European nominal morphology.

\section{Acknowledgments}

I wish to thank Michaël Peyrot (Leiden), Claudia A. Ciancaglini, Mauro Maggi (both Rome, Sapienza), Luca Alfieri (Rome, Marconi), and two anonymous reviewers for valuable and helpful comments on earlier drafts of this article. All opinions and errors remain entirely my responsibility.

\section{References}

Bailey, Harold W. 1979. Dictionary of Khotan Saka. Cambridge: Cambridge University Press.

Carling, Gerd. 2009. Dictionary and Thesaurus of Tocharian A. Part 1: A-J. In collaboration with Georges-Jean Pinault and Werner Winter. Wiesbaden: Harrassowitz.

Catt, Adam A. 2016. Tocharian B $l y(\breve{l})$ ptsentar: a new class VIII present. Tocharian and Indo-European Studies 17: 11-28.

Cheung, Johnny. 2002. Studies in the Historical Development of the Ossetic Vocalism. Wiesbaden: Reichert. 
DTB = Adams, Douglas Q. 2013. A Dictionary of Tocharian B. Revised and greatly enlarged. 2 vols. Amsterdam-New York: Rodopi

Emmerick, Ronald E. 1969. Notes on "The Book of Zambasta". Journal of the Royal Asiatic Society of Great Britain and Ireland 1: 59-74

Emmerick, Ronald E. 1980. $r$ - $/ n$-stems in Khotanese. In: Manfred Mayrhofer, Oskar E. Pfeiffer, \& Martin Peters (eds.), Lautgeschichte und Etymologie. Akten der VI. Fachtagung der Indogermanischen Gesellschaft, Wien, 24.-29. September 1978, 166-172. Wiesbaden: Reichert.

Emmerick, Ronald E. 1993. "[Numerals in] Iranian”. In: Jadranka Gvozdanović (ed.), Indo-European Numerals, 289-345. Berlin-New York: de Gruyter.

Ernout, Alfred E. 1914. Morphologie historique du latin. Paris: Klincksieck.

Hackstein, Olav. 2017. The phonology of Tocharian. In: Jared Klein, Brian Joseph, Matthias Fritz, \& Mark Wenthe (eds.), Handbook of Comparative and Historical IndoEuropean Linguistics. Vol. II, 1304-1335. Berlin-Boston: de Gruyter.

Hartmann, Markus. 2013. Das Genussystem des Tocharischen. Hamburg: Baar-Verlag.

Hilmarsson, Jörundur G. 1984. East Tocharian śorkäm 'peg' or ‘string'? Die Sprache 30.1: $16-28$.

Hilmarsson, Jörundur G. 1985. Tocharian B krorīyai (obl. sg.), A kror 'crescent, horn of the moon' Hitt. karawar 'horn' Arm. etjiwr 'horn' < I.-E. *ghrēur. Die Sprache 31.1: $40-47$.

Hilmarsson, Jörundur G. 1986. Studies in Tocharian Phonology, Morphology and Etymology with Special Emphasis on the $o$-Vocalism. Diss. Leiden.

Hilmarsson, Jörundur G. 1987. The element -ai(-) in the Tocharian nominal flexion. Die Sprache 33: 34-55.

Hilmarsson, Jörundur G. 1989. The Dual Forms of Nouns and Pronouns in Tocharian. Reykjavík: Málvísindastofnun Háskóla Íslands.

Hock, Hans H. 1991. Principles of Historical Linguistics, second edition. Berlin-New York: de Gruyter.

KEWA = Mayrhofer, Manfred. 1956-1980. Kurzgefasstes etymologisches Wörterbuch des Altindoarischen. Heidelberg: Winter.

Kim, Ronald I. 2019. The derivational history of Tocharian B war, A wär 'water'. In: Dieter Gunkel, Stephanie W. Jamison, Angelo O. Mercado, \& Kazuhiko Yoshida (eds.), Vina Diem Celebrent. Studies in Linguistics and Philology in Honor of Brent Vine, 141-151. Ann Arbor-New York: Beech Stave.

Klingenschmitt, Gert. 1994. Das Tocharische in indogermanistischer Sicht. In: Bernfried Schlerath (ed.), Tocharisch. Akten der Fachtagung der Indogermanischen Gessellschaft, Berlin, September 1990, 310-411. Reykjavík: Málvísindastofnun Háskóla Íslands.

Kloekhorst, Alwin. 2008. Etymological Dictionary of the Hittite Inherited Lexicon. Leiden: Brill. 
Kloekhorst, Alwin. 2013. Indo-European nominal ablaut patterns: The Anatolian evidence. In: Götz Keydana, Paul Widmer, \& Thomas Olander (eds.), Indo-European Accent and Ablaut, 107-128. Copenhagen: Museum Tusculanum Press.

Kortlandt, Frederik H.H. 2010. Studies in Germanic, Indo-European, and Indo-Uralic. Amsterdam-New York: Rodopi.

Kudara, Kōgi. 1974. “Tokara-go B-ni yoru abidaruma ronsho kankei-no danpen-ni tsuite. I. Abhidharmāvatāra-prakaraṇa chū [Fragments of the Abhidharma texts in Tocharian B: I. Commentary on the Abhidharmāvatāra- prakaraṇa]". In: T. Inokuchi (ed.), Saiiki-ni okeru kyōten rutsū-no shomondai [Some Aspects of the Buddhist Sūtras from Central Asia ], 21-36.

Lass, Roger. 199o. How to do things with junk: Exaptation in language evolution. Journal of Linguistics 26.1: 79-102.

Leukart, Alex. 1987. po-ro-qa-ta-jo, to-sa-pe-mo, a-mo-ra-ma and others: further evidence for Proto-Greek collective formations in Mycenaean and early alphabetic Greek. Minos 20-22: 343-365.

Leumann, Manu. 1977. Lateinische Laut- und Formenlehre. München: Beck.

Machek, Václav. 1957. Etymologický slovníkjazyka českého. Praha: Lidové noviny.

Malzahn, Melanie. 2014. Das Kollektivum im Tocharischen. In: Norbert Oettinger \& Thomas Steer (eds.), Das Nomen im Indogermanischen. Morphologie, Substantiv versus Adjektiv, Kollektivum. Akten der Arbeitstagung der Indogermanischen Gesellschaft vom 14. bis 16. September 2011 in Erlangen, 195-201. Wiesbaden: Reichert.

Malzahn, Melanie \& Fellner, Hannes A. 2015. Lifting up the light: tläś and lkäś in Tocharian A. Tocharian and Indo-European Studies 16: 61-79.

Miller, Jared L. 2008. Ein Ritual zur Reinigung eines Hauswesens durch eine Beschwörung an die Unterirdischen (CTH 446). In: Bernd Jankowski und Gernot Wilhelm (eds.), Omina, Orakel, Rituale und Beschwörungen, Texte aus der Umwelt des alten Testaments. (Neue Folge Band 4.), 206-217. Gütersloher Verslagshaus.

Nussbaum, Alan J. 2014. Feminine, abstract, collective, neuter plural: some remarks on each (expanded handout). In: Sergio Neri \& Roland Schuhmann (eds.), Studies on the Collective and Feminine in Indo-European from a Diachronic and Typological Perspective, 273-306. Leiden-Boston: Brill.

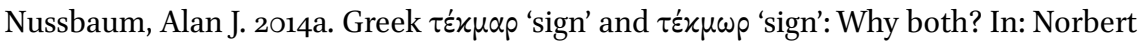
Oettinger \& Thomas Steer (eds.), Das Nomen im Indogermanischen. Morphologie, Substantiv versus Adjektiv, Kollektivum. Akten der Arbeitstagung der Indogermanischen Gesellschaft vom 14. bis 16. September 2011 in Erlangen, 215-26o. Wiesbaden: Reichert.

Olsen, Birgit Anette. 1999. The Noun in Biblical Armenian. Origin and Word-Formation. Berlin-New York: de Gruyter.

Panaino, Antonio C.D. 199o. Tištrya. Part I. The Avestan Hymn to Sirius. Roma: Istituto Italiano per il Medio ed Estremo Oriente. 
Petersen, Walter. 1939. The primary cases of the Tocharian nominal declension. Language 15.2: $72-98$.

Peyrot, Michaël. 2012. The Tocharian A match of the Tocharian B obl.sg. -ai. Tocharian and Indo-European Studies 13: 181-220.

Pinault, Georges-Jean. 2008. Chrestomathie tokharienne. Textes et grammaire. LeuvenParis: Peeters.

Pinault, Georges-Jean. 2011. Let us now praise famous gems. Tocharian and IndoEuropean Studies 12: 155-220.

Pinault, Georges-Jean. 2013. Body and soul: the reflexive in Tocharian. Indogermanische Forschungen 118: 339-359.

Pinault, Georges-Jean. 2015. Review of Markus Hartmann (2013). Bulletin de la Société de Linguistique de Paris 110.2: 178-197.

Rieken, Elizabeth. 1999. Untersuchungen zur nominalen Stammbildung des Hethitischen. Wiesbaden: Harrassowitz.

Ringe, Donald A. 1996. On the Chronology of Sound Changes in Tocharian. Volume 1: From Proto-Indo-European to Proto-Tocharian. New Haven: American Oriental Society.

Schindler, Jochem. 1967. Tocharische Miszellen. Indogermanische Forschungen 72: 239249 .

Simms, Douglas P.A. 2009. The words for 'fire' in Germanic. Journal of Germanic Linguistics 21.3: 297-333.

TEB = Krause, Wolfgang \& Thomas, Werner. 196o. Tocharisches Elementarbuch. I. Grammatik. Heidelberg: Winter.

de Vaan, Michiel. 2008. Etymological Dictionary of Latin and the Other Italic Languages. Leiden: Brill.

Van Windekens, Albert. 1944. Morphologie comparée du tokharien. Louvain: Bureaux du Muséon.

Van Windekens, Albert. 1976. Le tokharien, confronté avec les autres langues indo-européennes. Vol. I: La phonétique et le vocabulaire. Louvain: Centre International de Dialectologie Générale.

Weiss, Michael. 2009. Outline of the Historical and Comparative Grammar of Latin. Ann Arbor: Beech Stave Press.

Winter, Werner. 1965. Tocharian evidence [for laryngeals]. In: Werner Winter (ed.), Evidence for laryngeals, 212-213. The Hauge-London-Paris: Mouton. 